\title{
TTR
}

Traduction, terminologie, rédaction

\section{Barbara Folkart. Second Finding: A Poetics of Translation. Ottawa, University of Ottawa Press, 2007, 562 p.}

\section{Ryan Fraser}

Volume 21, numéro 1, 1er semestre 2008

La formation en traduction : pédagogie, docimologie et technologie I

Translator Training: Pedagogy, Evaluation, and Technologies I

URI : https://id.erudit.org/iderudit/029693ar

DOI : https://doi.org/10.7202/029693ar

Aller au sommaire du numéro

\section{Éditeur(s)}

Association canadienne de traductologie

ISSN

0835-8443 (imprimé)

1708-2188 (numérique)

Découvrir la revue

Citer ce compte rendu

Fraser, R. (2008). Compte rendu de [Barbara Folkart. Second Finding: A Poetics of Translation. Ottawa, University of Ottawa Press, 2007, 562 p.] TTR, 21(1),

247-256. https://doi.org/10.7202/029693ar

Tous droits réservés (c) TTR: traduction, terminologie, rédaction — Les auteurs, 2009
Ce document est protégé par la loi sur le droit d'auteur. L'utilisation des services d'Érudit (y compris la reproduction) est assujettie à sa politique d'utilisation que vous pouvez consulter en ligne.

https://apropos.erudit.org/fr/usagers/politique-dutilisation/ 
so is not easy given wide-spread perceptions of globalization as homogenization, standardization and translational assimilation, and of translation as imitation, misrepresentation and loss. Prevalent in critical discourses throughout the $20^{\text {th }}$ century, such perceptions reveal a generalized belief in the entropic decline in (translation's ability to maintain) cultural diversity which recent globalizing tendencies have consistently exacerbated. Refusing to give currency to this belief, Cronin redefines translation from a micro-cosmopolitan perspective as a negentropic cultural activity concerned with "the way in which translation contributes to and fosters the persistence and development of diversity" (129)—or, as he calls it, diversality, as opposed to universality. Rather than equating linguistic complexity with the failure of translation, he states that "it is because so much cannot be translated that much more remains to be translated" (130). Translation needs the fractal complexity of the local to exit, the understanding that the particular contains an image of the whole; it needs to show that "diversity persists in the elaborateness of the particular" (133) and that there is still something to express. Micro-cosmopolitanism thus implies an ethics of translation "which is predicated on complexity, distance and desire" (135), that is, on a connectedness that links the local to the global. As such, it "has much to tell us about how humans (...) live in a world where to know who you are means first and foremost knowing who others are" (143).

Gillian Lane-Mercier McGill University

\section{Barbara Folkart. Second Finding: A Poetics of Translation. Ottawa, University of Ottawa Press, 2007, 562 p.}

The title of Barbara Folkart's second academic monograph, Second Finding: A Poetics of Translation, is taken from Richard Wilbur's poem The Beautiful Changes (1988) $)^{1}$ and displayed on the book's cover in three experimental re-inscriptions, all set against a

1 Wilbur, Richard (c. 1988). New and Collected Poems. San Diego, New York, London, Harcourt Brace Jovanovich. 
magnified, shadowy and gloriously tactile-goose-fleshed and pock-marked-surface of writing paper.

These re-inscriptions speak directly to the impulses guiding her pen, I am convinced. The first appears to be a shadow cast deep in the background of the main title: this is an author with an academic career, a major book and numerous articles behind her; she could have chosen to rest on her laurels, fade quietly into the décor; instead, she produced this monograph that is fresh and contemporary (there are hundreds of newly minted pages here), pulling forward reflections from the past twenty years (she has re-worked and integrated a number of previously published pieces). The second re-inscription is in Folkart's own elegant cursive: this is an intensely personal work that rejects the turgid opacity of so much academic writing in favor of a genial simplicity of style in the first person; she even rejects the pronouns "he," "he/she," or "they" when referring to the generic third person; if it is not "I" that she is using, it is "she," the pronoun that speaks most intimately to her. The third re-inscription is in the scorched, bullet-wound typographymessy, ink-splattered from impact-of the antiquated manual typewriter: this is a confrontational book, often aggressively so; most of Folkart's major insights emerge from an argument structured in the form of antagonistic contradistinction as she pits her own vision of the poetically viable translation against an astounding list of canonized poets and critics whom she treats at times with utmost deference and admiration, and at times with the scorn of a poet vexed by the second-rate efforts of cobblers who refuse to "get it right."

The book is driven by two objectives. The first is to provide insight into the process of creating "poetically competent translations," to orient critical focus upon the translation act in its dynamic unfolding. Folkart's approach is resolutely "ad rem," rejects the tendency of theory to lose sight of the poet as "faber" (maker) and the poetic text as "facere" (process of making) in favor of "more or less extraneous constructs and discourses." (xiii) Every chapter contains a component of rigorous contrastive analysis with a workshop feel, in which she compares multiple translations of canonical poets, including her own, while providing wonderfully detailed insights into process. The second 
objective, inextricably wound up with the first, emerges as a polemic leitmotiv throughout and gives the book its teeth. This is Folkart's articulation of the standard by which she judges a translation to be "poetically competent" vs. "incompetent," or "writerly" vs. "readerly." This standard is re-iterated more or less comprehensively throughout. However, its most thorough and engaging explanations come nearly mid-way through and at the end of the game, in the third and ninth chapters respectively. Chapter 3, "The Valency of Poetic Imagery," is a reprisal of an article published in $2000 .^{2}$ A compelling piece on the poetic image as the intersection, both immediate and unmediated, of verb and flesh, where Ted Hugh's and Robin Robertson's "writerly" translations of Ovid (1994) ${ }^{3}$ are placed in contradistinction with the more "readerly" efforts of Amy Clampitt (1994) and Frank Justus Miller (1916), ${ }^{4}$ it sets the stage for the deeper reflections of chapter 9, entitled "Poetry as Knowing." Here is a manifesto of Folkart's philosophy of the poetic. Here is where she goes the furthest in defining the standard against which she judges the translational efforts and theoretical claims of her sparring partners. In its light, all of her-at face value often severe and sometimes unjust-criticisms in previous chapters come across as infinitely more "informed," "thought out." This amounts to something of an organizational deficiency of the book. For future editions, the third and ninth chapters need to be the first and second.

The type of cognition that Folkart proposes in these two chapters is the necessary condition for the type of text "ownership" or "mastery" that she posits as the first criterion for producing a poetically viable translation. A poetic mode of knowing, she argues, is an impulsive, intermittent, and ionizing connection with

2 Folkart, Barbara. (2000). "The Valency of Poetic Imagery." Athanor 2, 231-249.

3 Hoffmann, M. and J.Lasdun, Eds. (1994) After Ovid. London, Faber and Faber.

4 Ovid (1916). Metamorphoses. Ed. G.P. Goold. Trans. Frank Justus Miller. Bilingual edition. 1994. Trans. Amy Clampitt. Cambridge, Massachusetts, Harvard University Press, Loeb Classical Library. 
"the Real," defined as the "unsemiotized residue of experience that lurks in the crevices of the already-said." (61) In this sense, poetic responsivity occurs at a remove of profundity that is essentially beyond the text, beyond the sign. Translators, she contends, tend to trade only in the surface of the textual, which is always the "already said," the already semiotized, lexicalized, clichéd. A poetically responsive translator, in contrast, penetrates-using the instruments of ear and intuition - through the veil of the text and into the ionizing substratum of the Real, from where her translation emerges. Folkart's belief in profundities is classical to the core. But it is not, I think, a Socratic belief in unchanging and eternal essences. Rather, her thinking is more in line with the Stoics, specifically the Atomists, who first advanced the notion of matter's constitution in ionized movement, in a dynamic energy that immediately falsifies our perception of the world as a construct of placid and stable surfaces, of conventional appearances. In the Wilbur poem from which she derives her title, this energy is Beauty itself, made to jar perception by forever de-familiarizing the familiar, sundering "things and thing's selves for a second finding."

Folkart's standard for the poetically competent translation is well defined. It is this definition, however, that renders hopelessly vague the barometer by which any given translation can be judged as competent or incompetent, "writerly" or "readerly." For this barometer is not founded in the ratio but rather in the pathos, in esthesic responsivities, of which the most colorful expression comes in a quote from Emily Dickinson: "Does the poem take the top of your head off?"Now, the question is no longer "how well has the translator understood the text as a weave of first degree imagery and connotations," but rather "how well has the translator felt the text as one-off event, made its imagery, rhythmicity and musicality present in a visceral way."

To agree with Folkart in her assessments, we have to have an ear. And if our ear is tuned differently than hers? By no means does the vagueness of the measuring instrument-and she is the first to admit that it is vague-make what she contends invalid. What it means, rather, is a trade-off of sorts: the ear may be an ill-defined barometer, but it remains the only one adequate 
for measuring the poetic text; theory, on the contrary, may come in well-defined-and in this sense comforting-paradigms, but it remains an utterly inadequate barometer; better the right instrument than illusory comfort with the wrong one-is Folkart's contention here. Depending on what type of reader one is, great pleasure or displeasure can be derived in agreeing or disagreeing with the author in her assessments, or simply being entertained by her switch-blade rhetoric. On your average academic and her use of the average translation: "It is hard not to be dumbfounded by the way corpora keep getting obliterated by the very language that purports to be elucidating them, plastered over with opaque daubings of ill-digested lingo picked up second- or third-hand from amateurish translations into English.” (xvi)

Let it be understood, however, that this is confrontation at its most heroic, that is to say at its most courageous, forthright, and self-investing. Very rarely does Folkart play the sniper in these pages, criticize from the wings without risk to herself. In fact, she does what too few theorists ever do, lays her own skills as poet and translator on the line, pits her own versions against those of her opponents, and it is the insights generated by these confrontations, the insights of the poet (the faber) into the process of writing and translating poetry (the facere), that are this book's most valuable contribution. For me, the highlight is the sixth chapter, an analysis of T.S. Eliot's translation (1959) of Saint-John Perse's long poem Anabase (1972). ${ }^{6}$ "Contrastive analysis" is without doubt the better term here, because it takes the form of a protracted sparring match with Eliot. The chapter divides into two sections, the first and less interesting being an introduction to the corpus and to Eliot's translation. The second section, entitled simply "Process: Englishing Anabase" is where Folkart shines. It struck me in the reading that what we have

5 Eliot, T.S., trans. (1949). "Anabasis." St. John Perse Collected Poems. Complete edition with translations by W.H. Auden, Hugh Chisolm, Denis Devlin, T.S. Eliot, Robert Fitzgerald, Wallace Fowlie, Richard Howard, Louise Varèse. 1983. Bollingen Series LXXXVII. Princeton, Princeton University Press.

6 Perse, Saint-John (1972). Euvres complètes. Paris, Gallimard, Bibliothèque de la Pléiade. 
here is that rarest of commodities: a poet who not only translates but has a thorough command of the meta-language required to document the process of creating a translation that is poetry in its own right. Frictional oppositions of her own work-in-progress against Eliot's version and Perse's source generate tangents into sharp and subtle observations on the valence of poetic imagery, rhythmicity, and musicality, observations bespeaking the honed instinct, the finely tuned ear, of the poet.

Revelation in the form of antagonistic contradistinction informs Folkart's argument throughout. Chapters 1, 2, 4 and 5 are mostly re-worked materials from the last ten years. All stress the need for poetic translations to be "re-activations" or "re-enactments" of their sources, products of the same gesturing-forth that made their sources "inaugural." This, in contrast to translators' and theorists' tendency to "burrow back" into the "already-said." In chapter 1 , the latter is the source poem's irrelevant lexical dimension. Here, a number of unsatisfactory, lexically-driven translations of W.H. Auden's The Three Companions (1979) 7 - some of which were offered up by academic translators and theorists in a May 1998 workshop of the Canadian Association for Translation Studies-are set against a number of Folkart's own efforts. In chapters 2 and 4, the "already-said" comes in the form of (often irrelevant) historical and inter-textual discourses that lead translators to adopt mimetic strategies that fail not only at producing writerly translations, but also at achieving their principal aim-to give a sense of the source text's historicity or its dialogue with the inter-text. In chapter 2, Folkart sets her own modernizing English translation of Charles d'Orléans against the modern French versions of Albert Pauphilet (1952) ${ }^{8}$ and Jean-Claude Mühlethaler (1992), ${ }^{9}$

7 Auden, W.H. (1979). Selected Poems. Ed. Edward Mendelson. London, Faber and Faber.

8 Pauphilet, Albert, ed. (1952). Poètes et romanciers du moyen-age. Texte établi et annoté par Albert Pauphilet. Paris, Gallimard, Bibliothèque de la Pléiade.

9 Mühlethaler, Jean-Claude, ed. (1992). Ballades et rondeaux de Charles d'Orléans. Paris, Livre de Poche. 
and takes it upon herself, perhaps unfairly at times, to designate as "inter-textually non-valent" a number of poems laying claim to the status of "inter-textual." The highlight of chapter 4 is her discussion of the valent inter-textuality of Appollinaire's post-war poetry $(1959)^{10}$ and T.S. Eliot's The Waste Land (1930). ${ }^{11}$ Chapter 5 reprises the discourse of translation as creation vs. mimesis and has Folkart experimenting further with her own translations of d'Orléans and Appollinaire.

Chapters 7 and 8 are Folkart at her most polemic. She does not hold back in her effort to jar her fellow academics out of their comfortable paradigms. The validity of their notions, their competence in their field, and the soundness of their motivationsall are called out, challenged in an often scathing rhetoric. Out of these two chapters, two casualties of note-Lawrence Venuti and Luise von Flotow, both of whom are accused of pandering to selfserving agendas, subscribing "to a concept of authorship informed by an emphasis on the recognition (financial and other) they feel translators (themselves included) are owed." (401) Folkart's seventh chapter is an indictment of the "pre-scientific" notion of "visibility" and its metonymical slippage from its original use in the vindication of translated texts to its contemporary use in the vindication of translating agents themselves. Here, the modes of visibility that attract Folkart's ire are Venuti's notion of "resistant translation" (1995) $)^{12}$ —really a glorified form of cribbing that has misappropriated Berman's notion of "la lettre" (1999) 13 —and the type of post-feminist interventionism promoted by translators like Suzanne Jill Levine and Jeanne Prine, and academics like Luise von Flotow.

10 Apollinaire, Guillaume (1959). Euvres poétiques. Eds. Marcel Adéma, Michel Décaudin. Paris, Gallimard, Bibliothèque de la Pléiade.

11 Eliot, T.S. (1930). The Waste Land and Other Poems. New York, Harcourt Brace.

12 Venuti, Lawrence (1995). The Translator's Invisibility. A History of Translation. London, Routledge.

13 Berman, Antoine (1999 [1985]). La traduction et la lettre ou l'auberge du lointain. Paris, Seuil. 
Feminist interventionism is her target in chapter 7. Unfathomable to Folkart is the notion of intervening in texts deemed "oppressively male," of translating them in such a way as to make them "gender equitable" and thereby make the feminist translator "visible": "Why bother 'correcting' the man? Why not just let him hang by his own umbilical? By all means, do him in with a brilliant essay, savage him with an epigram, go for his jugular with a knife-edge counter-poem-but why on earth intervene in his text?" (324) And later on: "Interventionism in its most impoverishing form can regress to agenda-driven translations, in which the multi-layered complexities of the source text get flattened into the simple-minded linearities of an ideological template." (325) What follows is Folkart at her sharpest critically as she meticulously counter-analyzes Louise Labés Sonnet V as translated by Jeanne Prine and commented by Luise von Flotow (1997). ${ }^{14}$ The result is a vexed dismissal of both Prine's endeavor and von Flotow's assessment of it: "Given the sloppiness of the undertaking, and its all-round deficiencies, von Flotow's comment on the rigors of such feminist research (and its beneficial impact on critical translation studies as a whole) has the hollow ring of boilerplate to it." (330)

Extending naturally out of the question of "visibility" in chapter 7 is that of "authorship" in chapter 8. Here, Folkart continues her attack on Venuti's "resistant translation"-she renames it "grainy" translation-while excoriating his position that both source texts and translations are "derivative," and that consequently, "translatorship" should be deemed equal to "authorship." The notion that "'replicating,' 'imitating,' or-in the best-case scenario-'re-enacting... an already finished product" is the same thing as "making something more or less inaugural out of the pre-existing materials made available to you by your language, the literary tradition within which you're working, [and] your culture as a whole," is slowly and carefully, through a meticulous comparison of source texts with translations that lay claim to ownership (mastery over the source text and language materials that make it up) and authorship (recognition of having

14 Flotow, Luise von (1997). Translation and Gender. ManchesterOttawa: St. Jerome Publishing-University of Ottawa Press. 
produced a target text the way a poet would produce her source), dismantled as a patent absurdity. [343] Folkart cuts to the quick. The translations that she attacks are Venuti's own. Not only does she deflate their claim to authorship by describing them as the worst form of cribbing passed off as "resistant translation," but she questions Venuti's ownership of his sources as well, uncovers deficiencies in his understanding of Italian, some of which he had been confronted with by other scholars but would not admit to, choosing instead to throw up a smoke screen of pseudophilosophical justifications.

Venuti and von Flotow are in good company, however. These more targeted criticisms point up a malaise with theory in general, which trades in "readerly, retrospective, after-thefact constructs that have little to say about making a text. From the creative standpoint, they are dead ends rather than points of departure." (13) Yet for all of its cantankerousness, Folkart's discourse is by no means "anti-theoretical," nor even "posttheoretical." I choose to view it, rather, as trans-theoretical, one that seeks to move beyond the limits of what theory can revealbeyond the poem as "product" or "artifact," as semiotic weave whose strands may be teased apart and analyzed "post-mortem"and into the uncharted territory of the facere, the dynamic "making forces that drive the poem into being." (13) Folkart stands at a threshold here, over which she gazes ambitiously and against which she raps, at times, with a great deal of frustration. However, the value of having traveled the path of theoretical discourse to reach this threshold cannot be underestimated. Folkart's newfound iconoclasm cuts a path straight through the very best that theory has to offer, and it should not be forgotten that this is a scholar who has transacted extensively with, and greatly enriched, the same models that she appears to decry here (Le conflit des énonciations [1991] ${ }^{15}$ ). In this way she is much closer to Meschonnic than to Berman, to whom she dedicates the book. Unfortunately, at times she also echoes the cynicism with which Meschonnic reflects back on the failure of theory-that of "the sign" - and its exponents. Yet she has, perhaps without

15 Folkart, Barbara (1991). Le conflit des énonciations : traduction et discours rapporté. Candiac, Montréal : Les Éditions Balzac. 
even realizing it, offered in the book's title and the Wilbur poem an antidote to such cynicism. Why should theoretical discourse be "insufficient," "a dead end"? Is it not, like any placid surface of the world, forever subject to transformation, a sea-change, to the self-sundering wrought by the Real? Should the conviction of theory's insufficiency manifest as a bitter disappointment, or as a "second finding," a "loss back to wonder"?

\section{Ryan Fraser University OF OtTAWA}

\section{Georges L. Bastin and Paul F. Bandia, eds. Charting the Future of Translation History. Ottawa, University of Ottawa Press, 2006, 344 p.}

If a single keyword were to be selected from all 17 essays that make up Charting the Future of Translation History, that would be "gaps". This collection of studies, drawn from the XVII ${ }^{\text {th }}$ Annual Conference of the Canadian Association for Translation Studies (CATS), attempts to point at several lacunae surrounding research on the history of translation since the mid-1960s. Contributors discuss both translation as the object of historical study and history as the object of translation studies-i.e. the role of translation in the (de)construction of history.

The book is divided into two main blocks: 'Methodology' and 'Current Discourses.' In the former, seven renowned specialists discuss contemporary discourses on translation research; in the latter, ten case studies map translation in geographical and temporal zones. "Blank Spaces in the History of Translation" by Julio-César Santoyo reflects on neglected areas of translation and interpreting studies while summarizing the history of oral interpretation, intracultural translation, pseudo and selftranslations, and translational mistakes. Particularly remarkable is his approach regarding the silent protagonism of translation in the construction of history, and the need to de-Westernize it by exposing texts outside the European tradition. 